\title{
The Antibacterial Activity of some Red Sea Soft Corals species
}

\author{
Hassan A.H. Ibrahim ${ }^{1}$, Saad Z. Mohamed ${ }^{2}$, Aml Z. Farhat ${ }^{3}$, and \\ Mohamed A. Abu El-Regal ${ }^{4}$
}

1- Microbiology Lab., National Institute of Oceanography and Fisheries, Alexandria Branch.

2-Marine Biology Department, Faculty of Science, Suez Canal University.

3- Marine Environment Division, National Institute of Oceanography \& Fisheries, Hurghada branch.

4- Marine Science Department, Faculty of Science, Port Said University. E-mail: doctorhassan10@yahoo.com.

\section{ABSTRACT}

The present study aimed to investigate the antibacterial properties of crude extracts from some soft coral species from the Red Sea, Hurghada, Egypt. Crude extracts of Lobophytum pauciliforum, Dendronephthya hemprichi, Sarcophyton gracile, Sarcophyton glaucum, Sinularia gardineiri, Sinularia leptoclados, Nephthea pacifica, Sarcophyton acutum, Sarcophyton spongosium and Xenia macrospiculata, were tested against fish and human pathogenic bacteria. The well cut - diffusion technique was used to determine the absolute activity units (AU) and the minimal inhibitory concentrations (MICs) using disc-diffusion technique were determined against the most affected bacterial pathogens (E. coli and $S$. aureus). The AU of the ethanolic crude extract ranged from 1.4 to 25.0 for Sarcophyton acutum and Lobophytum pauciliforum, respectively. On the other side, ethyl acetate crude extracts showed the highest AU (16.0) for L. pauciliforum against $S$. aeurus, followed by (11.1) of $N$. pacifica and X. macrospiculata against). The MIC of L. pauciliforum ethyl acetate crude extract was recorded as $\left(50 \mathrm{mg} \mathrm{ml}^{-1}\right)$ against both $E$. coli and $S$. areaus ATCC 6358.

Extracts from some soft corals showed the ability to inhibit the growth of some pathogenic bacteria indicating that it could be used for medical purposes.

Keywords: Antibacterial activity, Soft corals, MIC, Cytotoxicity.

\section{INTRODUCTION}

The ocean is considered to be a great source of potential drugs, and hence marine natural products have attracted the attention of biologists and chemists for the past five decades (Bhakuni and Rawat, 2005). Over 5000 novel compounds have been isolated from shallow waters to 900-m depths of the sea (Somnath and Ghosh, 2010). The recent studies on the bioactive compounds isolated from marine organisms have shown that they have anti-cancer, anti-bacterial, anti-fungal or anti-inflammatory and other pharmacological activities (Borowitzka and Borowitzka, 1992; Febles et al., 1995; Mayer and Hamann, 2005; Somnath and Ghosh, 2010). Chemicals such as alkaloids, phenols, steroids, terpenoids, are secondary metabolites that have toxicological, pharmacological and ecological significance (Somnath and Ghosh, 2010). The evolutionary success of soft corals in areas of high levels of predation has been attributed to their production of significant amounts of secondary metabolites, especially terpenes (Sammarco et Al.,1985). Many soft corals show predator deterrence activity (Coll et al., 1982; Taglialatela-Scafati et al., 2002). Soft corals elaborate a large variety of sesquiterpenoids and diterpenoids. Several of these are found to be toxic. Guaiazulene from the gorgonian Euplexaura erecta exhibits mild 
activity against Pseudomonas aeruginosa. Subergorgic acid, a cardiotoxin, is obtained from the Pacific gorgonian coral Subergorgia suberosa (Groweiss et al., 1985). Pseudopterolide, an unusual diterpene with a 12-member ring from the gorgonian Pseudopterogorgia acerosa shows unusual cytotoxic properties (Banduraga et al., 1982). The soft corals are very widespread throughout the tropical Indo-Pacific area including the Red Sea. The Red Sea reefs are made up of four main families; Xeniidae, Nephtheidae, Alcyoniidae and Tubiporidae containing about 250 species. All of these families and species are found scattered abundantly along the reefs of the Red Sea coast. Although they are abundant on the Red Sea reefs, a few studies on the soft corals were carried out in comparison to hard corals. Most of the studies focused on their abundance, diversity and growth. However, studies on the biological and microbial activities on the Red Sea soft corals are almost lacking. Thus, the present study was suggested to investigate compounds extracted from some soft coral species common in the Red Sea at Hurghada, Egypt and whether they are effective in curing some microbial infections. In addition, MICs and cytotoxicity were demonstrated.

\section{MATERIALS AND METHODS}

\section{Sampling of soft corals}

Soft corals were sampled off the National Institute of Oceanography and Fisheries at Hurghada on the Egyptian Red Sea coast. Ten species were collected using SCUBA diving technique and identified (Thomson \& Dean, 1931; Gohar, 1940; Ezz Al-Arab, 2009). The samples were then washed by distilled water and frozen for further the purpose of extraction of bioactive substances.

\section{Preparation of soft coral crude extracts}

Fifty grams of each soft coral sample were macerated with $100 \mathrm{ml}$ of $70 \%$ aqueous ethanol and ethyl acetate solvents. After soaking for two weeks with shaking twice daily, they were filtered through Whatman 542 filter paper. Ethanol and ethyl acetate solvents were evaporated using rotary evaporator to obtain crude extracts (Ballantine, 1987).

\section{Antibacterial activity against indicator strains}

\section{1- Well-cut diffusion technique:}

Fifty millimeters of nutrient agar medium inoculated with indicator microorganisms $(0.5 \%)$ were poured into plates. After solidifying, wells were punched out using $0.5 \mathrm{~cm}$ cork borer, and each of their bottoms was then sealed with two drops of crude extract. All plates were incubated at appropriate temperature for 24-48 hrs. After incubation period, the radius of clear zone around each well (Y) and the radius of the well $(X)$ were linearly measured in $\mathrm{mm}$, where dividing $\mathrm{Y}^{2}$ over $\mathrm{X}^{2}$ determines an absolute unit (AU) for the clear zone. The absolute unit of each crude extract, which indicates a positive result in the antimicrobial action, was calculated according to the following equation (El-Masry et $a l ., 2002$ ):

$$
\mathrm{AU}=\pi \mathrm{Y}^{2} / \pi \mathrm{X}^{2}
$$

\section{2- Pouring technique}

Nutrient agar was prepared and then $24 \mathrm{hrs}$ old - indicator strain was added in $0.1 \%$. The crude extracts were added to yield 1,2,3,4, and 5\%. Control was prepared without any crude. After incubation period, the count of indicator pathogen used was determined. Comparing the treated with crude extracts to control, then the suppression percentages were calculated according to the following equation (Al-Ajlani and Hasnain, 2006): 


$$
\text { Suppression } \%=\frac{\text { C control }-\mathrm{C} \text { treatment }}{\mathrm{C} \text { control }} \times 100
$$

Where: (C) refers to bacterial count as $\mathrm{cfu} \mathrm{ml}^{-1}$.

Minimal inhibitory concentrations (Parveez et al., 2007)

The MICs were detected by applying eight concentrations in mg per one $\mathrm{ml}$ for each crude extract obtained either by ethanol $70 \%$ or ethyl acetate. All crude extracts were prepared as stock solutions of $50 \mathrm{mg} / \mathrm{ml}$. All selection agents were filter sterilized and stored at $4^{\circ} \mathrm{C}$. Diagnostic sensitivity test (D.S.T.) agar medium was autoclaved and cooled to $50^{\circ} \mathrm{C}$ in a water bath prior to the addition of the indicator bacteria (Escherichia coli, and Staphylococcus aureus ATCC 6538). All crude extracts were added to the concentrations of 25, 50, 75, 100, 200, 300, and 500, 700 and $900 \mathrm{mg} \mathrm{l}^{-1}$. Three replicates (plates) were used for each treatment as well as the control. The means of replicates were used in the final calculations.

Cytotoxicity assay (Dvorak et al., 1999)

This assay was applied to detect the cytotoxicity of ethanolic crude extracts against brine shrimp; Artemia salina used successfully in the aquaculture feeding of fish and shrimps larvae and other invertebrates. Several ratios $(1,3,5,10,20$, and $50 \%)$ of crude extracts were added into Artemia salina culture and then count was followed daily for four days. All the counts obtained were compared to control (without any crude extracts). Using the values on died individuals in given concentrations determines the percent of mortality according the following formula:

Where:

$$
\mathbf{M m}_{\mathrm{ct}}=\mathbf{N}_{\mathrm{Mm}} \cdot \mathbf{1 0 0} / \mathbf{N}_{\mathbf{0}}
$$

$\boldsymbol{M m} \boldsymbol{m}_{c t}$ is mortality of individuals in time t $(\%), N_{M m}$ is average number of dead individuals, $N_{\boldsymbol{0}}$ is initial number of living individuals put into every concentration at the test start. The $\mathrm{EC}_{50}$ values were assessed using non-linear regression, where mortality is related to decimal logarithm of concentration.

Individual EC values were determined for each replicate separated and average value should be determined afterwards. $\mathrm{EC}_{50}$ values cannot differ more than $30 \%$.

\section{RESULTS}

\section{Screening of antibacterial activity of Red Sea soft coral}

Ten species of soft corals were tested for the antimicrobial activities. These species were Lopophytom pauciliforum, Dendronephthya hemprichi, Sarcophyton gracile, Sarcophyton galucum, Sarcophyton spongosium, nephthyea pacifica, Sarcophyton acutum, Sinularia gardinieri, Xenia macrospiculata. Sinularia leptoclados.

In general, the crude extracted from the ten soft coral species showed positive records against at least two bacterial pathogens. The results in (Table 1) confirmed that the absolute activity units (AU) of the ethanolic crude extract ranged from 1.4 to 25.0 for Sarcophyton acutum and Lopophytum pauciliforum, respectively. 
Table 1: Screening the antibacterial activity of ethanolic crude extracts of soft corals species using well cut - diffusion technique

\begin{tabular}{|c|c|c|c|c|c|c|c|}
\hline \multirow[t]{2}{*}{ Soft coral species } & \multicolumn{7}{|c|}{ Antibacterial activity $\left(\mathrm{AU}^{*}\right)$} \\
\hline & S.a. & E.c. & S.f. & P.a. & B.c. & V.d. & $V . f$. \\
\hline L. pauciliforum & 5.9 & 25.0 & 1.7 & 4.0 & 3.8 & - & 1.6 \\
\hline Dendronephthea hemprichi & - & - & - & - & - & - & - \\
\hline S. gracile & - & - & - & - & - & - & - \\
\hline S. glaucum & 1.7 & 18.4 & 4.0 & 8.2 & 1.5 & 1.8 & 2.7 \\
\hline S. gardineiri & - & - & - & - & - & - & - \\
\hline N. pacifica & - & - & - & - & - & - & - \\
\hline S. acutum & - & 7.6 & - & - & - & - & - \\
\hline S. leptoclados & - & - & - & - & - & - & - \\
\hline S. spongosium & - & - & 7.1 & 2.3 & - & 1.4 & - \\
\hline X. macrospiculata & 2.3 & 6.1 & 2.8 & 1.7 & 1.7 & 1.9 & 2.2 \\
\hline
\end{tabular}

The highest activity (25.0 and 18.4) were recorded against E. coli. This was occured by L. pauciliforum and S. glaucum. These values followed by 8.2 and 5.9 for $S$. glaucum against $P$. aueroginosa and for $L$. pauciliforum against $S$. auerus, respectively. On the other side, ethyl acetate crude extracts showed the highest AU (16.0) for L. pauciliforum against S. aeurus, followed by (11.1) of N. pacifica and $X$. macrospiculata against $S$. aeurus (Table 2).

Table 2: Screening the antibacterial activity of ethyl acetate crude extracts of soft corals species using well cut - diffusion technique

\begin{tabular}{lccccccc}
\hline \multicolumn{1}{c}{ Soft coral species } & \multicolumn{7}{c}{ Antibacterial activity $\left(\mathrm{AU}^{*}\right)$} \\
\cline { 2 - 8 } & S.a. & E.c. & E.f. & P.a. & B.c. & V.d. & V.f. \\
\hline L. pauciliforum & 16.0 & 9.9 & 9.9 & 8.2 & 2.6 & 1.4 & 8.2 \\
Dendronephthea & 6.3 & 6.6 & 2.2 & 6.6 & - & - & 5.9 \\
S. gracile & - & 1.5 & - & 1.3 & - & - & - \\
S. glaucum & 1.7 & 1.9 & 1.5 & 1.6 & 1.8 & 1.2 & 1.4 \\
S. gardineiri & - & 4.0 & - & 3.4 & - & - & - \\
N. pacifica & 2.9 & 5.2 & 1.9 & 11.1 & 1.7 & 1.2 & 1.8 \\
S. acutum & - & 6.1 & - & 2.3 & - & - & - \\
S. leptoclados & 2.1 & - & - & - & - & - & 2.3 \\
S. spongosium & - & 2.2 & - & 7.1 & - & - & - \\
X. macrospiculata & 4.0 & 7.1 & 3.3 & 11.1 & 2.3 & 1.6 & 4.0 \\
\hline
\end{tabular}

S.a.= S. auerus ATCC 6538, E.c.= Escherichia coli, S.f.= Enterococcus faecalis, P.a. $=$ Pseudomonas aeruginosa ATCC 8739, B.c. $=$ Bacillus cereus ATCC 1318, V.d.= Vibrio damsela and V.f.= Vibrio fulvilalis

However, the extract of $L$. pauciliforum was the most effective in the inhibition of all tested bacterial pathogens. On contrary, the extracts of $S$. gracile, S. acutum and $S$. spongosium were the lowest effective against these indicators. From these results, it was noted that the crude extracts of $L$. pauciliforum had a broad spectrum antimicrobial effect against all indicator microorganisms. In addition, the crude extracts of $S$. glaucum, $N$. pacifica and X. macrospiculata had considerable effect in the inhibition of indicator bacteria tested here. Moreover, the highest results of antibacterial activities are shown as inhibition zones in several macrogarphs (Fig.1). To confirm the efficacy of the most effective crude extracts of soft corals $(L$. pauciliforum, $S$. glaucum, $N$. pacifica and X. macrospiculata), the suppression percentages in bacterial count $(\mathrm{cfu} / \mathrm{ml})$ for the most affected bacterial pathogens were demonstrated using different concentrations (1-5\%). The most suppression 
percentages against E. coli were recorded for L. pauciliforum as of $74 \%$ and $70 \%$ for ethanol crude and ethyl acetate crude extract. Generally, the suppression percentages ranged from $31-74 \%$ for all ratios examined. The highest suppression percentages against $P$. aeruginosa were recorded as $52 \%$ for $N$. pacifica and as $48 \%$ for $X$. macrospiculata for ethyl acetate crude extract, respectively. Generally, the suppression percentages ranged from 31- 52\% for all ratios examined. The most suppression percentages against $P$. aeruginosa were recorded as of $38 \%$ for $N$. pacifica and as of $34 \%$ for X. macrospiculata for ethanolic crude extract. Generally, the suppression percentages ranged from $0-38 \%$ for all ratios examined. However, all of these pathogens were strongly affected in the ascending direction, i.e. the more the concentration of crude extract, the higher the suppression percentage of the bacterial pathogen. These results revealed the efficacy of the soft coral extracts.

\section{Minimal inhibitory concentrations}

The minimum inhibitory concentrations (MICs) are represented in Table (3) and Macrographs in Fig. (2). The MIC of L. pauciliforum ethanolic crude extract was recorded as $300 \mathrm{mg} \mathrm{ml}^{-1}$ against both $E$. coli and $S$. areaus ATCC 6358. Whereas, the MIC of L. pauciliforum ethyl acetate crude extract was recorded as $50 \mathrm{mg} \mathrm{ml}^{-1}$ against both $E$. coli and $S$. areaus ATCC 6358. The MIC of $S$. galucum ethanolic crude extract was recorded as $500 \mathrm{mg} \mathrm{ml}^{-1}$ against E. coli and $\left(300 \mathrm{mg} \mathrm{ml}^{-1}\right)$ S. areaus ATCC 6358. Whereas, the MIC of $S$. galucum ethyl acetat crude extract was recorded as $\left(300 \mathrm{mg} \mathrm{ml}^{-1}\right)$ against both $E$. coli and $S$. areaus ATCC 6358. The MIC of $N$. pacifica ethanolic crude extract was recorded as $\left(700 \mathrm{mg} \mathrm{ml}^{-1}\right)$ against $E$. coli and (300 mg ml $\mathrm{m}^{-1}$ ) S. areaus ATCC 6358. Whereas, the MIC of $N$. pacifica ethyl acetat crude extract was recorded as $\left(50 \mathrm{mg} \mathrm{ml}^{-1}\right)$ against both E. coli and $S$. areaus ATCC 6358. The MIC of X. macrospiculata ethanolic crude extract was recorded as (300 $\mathrm{mg}$ $\mathrm{ml}^{-1}$ ) against both $E$. coli and $S$. areaus ATCC 6358. Whereas, the MIC of $X$. macrospiculata ethyl acetat crude extract was recorded as $\left(500 \mathrm{mg} \mathrm{ml}^{-1}\right)$ against $E$. coli and $\left(100 \mathrm{mg} \mathrm{ml}^{-1}\right)$ S. areaus ATCC 6358.

Table 3: Minimal inhibitory concentrations (MICs) of ethanolic and ethyl acetate crude extacts from selected soft coral against $E$. coli and $S$. aureus

\begin{tabular}{|c|c|c|c|c|c|c|c|c|c|}
\hline \multirow[t]{2}{*}{ Species } & \multicolumn{9}{|c|}{ Concentration of crude extract $\left(\mathrm{mg} \mathrm{ml}^{-1}\right)$} \\
\hline & 25 & 50 & 75 & 100 & 300 & 500 & 700 & 900 & 1000 \\
\hline L. pauciliforum ${ }^{\mathrm{a}}$ & $\begin{array}{l}\mathrm{nil}^{\mathrm{E}} \\
\mathrm{nil}^{\mathrm{S}}\end{array}$ & $\begin{array}{l}\mathrm{nil}^{\mathrm{E}} \\
\mathrm{nil}^{\mathrm{S}}\end{array}$ & $\begin{array}{l}\mathrm{nil}^{\mathrm{E}} \\
\mathrm{nil}^{\mathrm{S}}\end{array}$ & $\begin{array}{l}\mathrm{nil}^{\mathrm{E}} \\
\mathrm{nil}^{\mathrm{S}}\end{array}$ & $\frac{7^{E}}{7^{S}}$ & $\begin{array}{l}12^{\mathrm{E}} \\
11^{\mathrm{S}}\end{array}$ & $\begin{array}{l}15^{\mathrm{E}} \\
14^{\mathrm{S}}\end{array}$ & $\begin{array}{l}18^{\mathrm{E}} \\
18^{\mathrm{S}}\end{array}$ & $\begin{array}{l}26^{\mathrm{E}} \\
24^{\mathrm{S}}\end{array}$ \\
\hline L. pauciliforum ${ }^{\mathrm{b}}$ & $\begin{array}{l}\mathrm{nil}^{\mathrm{E}} \\
\mathrm{nil}^{\mathrm{S}}\end{array}$ & $\frac{7^{E}}{7^{s}}$ & $\begin{array}{l}7^{E} \\
7^{S}\end{array}$ & $\begin{array}{l}10^{\mathrm{E}} \\
8^{\mathrm{S}}\end{array}$ & $\begin{array}{l}\overline{12} \\
10^{\mathrm{E}}\end{array}$ & $\begin{array}{l}16^{\mathrm{E}} \\
14^{\mathrm{S}}\end{array}$ & $\begin{array}{l}20^{\mathrm{E}} \\
18^{\mathrm{S}}\end{array}$ & $\begin{array}{l}25^{\mathrm{E}} \\
23^{\mathrm{S}}\end{array}$ & $\begin{array}{l}28^{\mathrm{E}} \\
26^{\mathrm{S}}\end{array}$ \\
\hline S. glaucum $^{\mathrm{a}}$ & $\begin{array}{c}\mathrm{nil}^{\mathrm{E}} \\
\mathrm{nil}^{\mathrm{S}}\end{array}$ & $\begin{array}{c}\mathrm{nil}^{\mathrm{E}} \\
\mathrm{nil}^{\mathrm{S}}\end{array}$ & $\begin{array}{l}\mathrm{nil}^{\mathrm{E}} \\
\mathrm{nil}^{\mathrm{S}}\end{array}$ & $\begin{array}{c}\mathrm{nil}^{\mathrm{E}} \\
\mathrm{nil}^{\mathrm{S}}\end{array}$ & $\begin{array}{l}\operatorname{nil}^{\mathrm{E}} \\
\underline{7}^{\mathrm{S}}\end{array}$ & $\frac{7^{E}}{10} s$ & $\begin{array}{l}11^{\mathrm{E}} \\
17^{\mathrm{S}}\end{array}$ & $\begin{array}{l}16^{\mathrm{E}} \\
20^{S}\end{array}$ & $\begin{array}{l}18^{\mathrm{E}} \\
21^{\mathrm{S}}\end{array}$ \\
\hline S. glaucum $^{\mathrm{b}}$ & $\begin{array}{l}\mathrm{nil}^{\mathrm{E}} \\
\mathrm{nil}^{\mathrm{S}}\end{array}$ & $\begin{array}{l}\mathrm{nil}^{\mathrm{E}} \\
\mathrm{nil}^{\mathrm{S}}\end{array}$ & $\begin{array}{l}\mathrm{nil}^{\mathrm{E}} \\
\mathrm{nil}^{\mathrm{S}}\end{array}$ & $\begin{array}{l}\mathrm{nil}^{\mathrm{E}} \\
\mathrm{nil}^{\mathrm{S}}\end{array}$ & $\frac{7^{E}}{7^{S}}$ & $\begin{array}{l}12^{\mathrm{E}} \\
9^{\mathrm{S}}\end{array}$ & $\begin{array}{l}15^{\mathrm{E}} \\
14^{\mathrm{S}}\end{array}$ & $\begin{array}{l}18^{\mathrm{E}} \\
18^{\mathrm{S}}\end{array}$ & $\begin{array}{l}20^{\mathrm{E}} \\
22^{\mathrm{S}}\end{array}$ \\
\hline N. pacifica ${ }^{\mathrm{a}}$ & $\begin{array}{l}\operatorname{nil}^{\mathrm{E}} \\
\text { nil }^{\mathrm{S}}\end{array}$ & $\begin{array}{l}\mathrm{nil}^{\mathrm{E}} \\
\mathrm{nil}^{\mathrm{S}}\end{array}$ & $\begin{array}{l}\mathrm{nil}^{\mathrm{E}} \\
\mathrm{nil}^{\mathrm{S}}\end{array}$ & $\begin{array}{l}\mathrm{nil}^{\mathrm{E}} \\
\mathrm{nil}^{\mathrm{S}}\end{array}$ & $\begin{array}{l}\operatorname{nil}^{\mathrm{E}} \\
7^{\mathrm{S}}\end{array}$ & $\begin{array}{l}\operatorname{nil}^{\mathrm{E}} \\
11^{\mathrm{S}}\end{array}$ & $\frac{7^{E}}{16} s$ & $\begin{array}{l}13^{\mathrm{E}} \\
20^{S}\end{array}$ & $\begin{array}{l}16^{\mathrm{E}} \\
24^{\mathrm{S}}\end{array}$ \\
\hline N. pacifica ${ }^{\mathrm{b}}$ & $\begin{array}{l}\mathrm{nil}^{\mathrm{E}} \\
\mathrm{nil}^{\mathrm{S}}\end{array}$ & $\frac{7^{\mathrm{E}}}{7^{\mathrm{s}}}$ & $\begin{array}{l}8^{\mathrm{E}} \\
9^{\mathrm{S}} \\
\end{array}$ & $\begin{array}{l}10^{\mathrm{E}} \\
9^{\mathrm{S}}\end{array}$ & $\begin{array}{l}\overline{12^{\mathrm{E}}} \\
13^{\mathrm{S}}\end{array}$ & $\begin{array}{l}15^{\mathrm{E}} \\
15^{\mathrm{S}}\end{array}$ & $\begin{array}{l}18^{\mathrm{E}} \\
18^{\mathrm{S}}\end{array}$ & $\begin{array}{l}20^{\mathrm{E}} \\
22^{\mathrm{S}}\end{array}$ & $\begin{array}{l}23^{\mathrm{E}} \\
27^{\mathrm{S}}\end{array}$ \\
\hline X. macrospiculata ${ }^{\mathrm{a}}$ & $\begin{array}{l}\mathrm{nil}^{\mathrm{E}} \\
\text { nil }^{\mathrm{S}}\end{array}$ & $\begin{array}{c}\mathrm{nil}^{\mathrm{E}} \\
\mathrm{nil}^{\mathrm{S}}\end{array}$ & $\begin{array}{l}\mathrm{nil}^{\mathrm{E}} \\
\mathrm{nil}^{\mathrm{S}}\end{array}$ & $\begin{array}{l}\mathrm{nil}^{\mathrm{E}} \\
\mathrm{nil}^{\mathrm{S}}\end{array}$ & $\frac{7^{E}}{7^{s}}$ & $\begin{array}{l}10^{\mathrm{E}} \\
9^{\mathrm{S}}\end{array}$ & $\begin{array}{l}12^{\mathrm{E}} \\
13^{\mathrm{S}}\end{array}$ & $\begin{array}{l}14^{\mathrm{E}} \\
15^{\mathrm{S}}\end{array}$ & $\begin{array}{l}15^{\mathrm{E}} \\
15^{\mathrm{S}}\end{array}$ \\
\hline X. macrospiculata ${ }^{\mathrm{b}}$ & $\begin{array}{l}\mathrm{nil}^{\mathrm{E}} \\
\text { nil }^{\mathrm{S}}\end{array}$ & $\begin{array}{l}\mathrm{nil}^{\mathrm{E}} \\
\mathrm{nil}^{\mathrm{S}}\end{array}$ & $\begin{array}{l}\mathrm{nil}^{\mathrm{E}} \\
\mathrm{nil}^{\mathrm{S}}\end{array}$ & $\begin{array}{l}\text { nil }^{\mathrm{E}} \\
7^{\mathrm{S}}\end{array}$ & $\begin{array}{l}\mathrm{nil}^{\mathrm{E}} \\
11^{\mathrm{S}}\end{array}$ & $\frac{7^{E}}{14^{E}}$ & $\begin{array}{l}10^{\mathrm{E}} \\
16^{\mathrm{S}}\end{array}$ & $\begin{array}{l}12^{\mathrm{E}} \\
20^{\mathrm{S}}\end{array}$ & $\begin{array}{l}14^{\mathrm{E}} \\
25^{\mathrm{S}}\end{array}$ \\
\hline
\end{tabular}

symbole: $\mathrm{a}=$ ethanol crude extract $(70 \%), \mathrm{b}=$ ethyl acetate crude extract, $\mathrm{E}=\mathrm{E}$. coli and $S=S$. aureus. All numbers expressed in millimeters $(\mathrm{mm})$ for inhibition zone around each disc. Each disc was saturated with $25 \mu 1$. Numbers underlined expressed for MIC for each crude extract. 


\section{Cytotoxicity assay}

In order to determine the cytotoxicty effect of bioactive compounds present in selected soft corals to be recommended in application, the EC50 value of ethanolic crude extracts was investigated (Table 4). Both concentrations 1 and 3\% of ethanolic crude extracts did not show any mortality at EC50 for four days; the incubation period of toxicity experiment. Whereas, the concentration 5\% showed mortality (EC50) after the fourth day ranged between $50-55 \%$ for extracts of L. pauciliforum, S. glaucum, $N$. pacifica and $X$. macrospiculata, respectively. The concentration $10 \%$ showed mortality (EC50) after the second day for extract of X. macrospiculata only, and after the third day ranged between $50-65 \%$ for extracts of L. pauciliforum, S. glaucum, $N$. pacifica and X. macrospiculata, respectively. Moreover, such concentration showed mortality at EC50 after the fourth day ranged between $65-75 \%$ for extracts of $L$. pauciliforum, S. glaucum, $N$. pacifica and $X$. macrospiculata, respectively. The concentration $20 \%$ showed mortality (EC50) after the second day ranged between 50$58 \%$ for extracts of L. pauciliforum, S. glaucum, $N$. pacifica and X. macrospiculata, respectively, and ranged between $63-75 \%$ for the same extracts after the third day. Moreover, such concentration showed mortality at EC50 after the fourth day ranged between $78-88 \%$ for the same extracts. The concentration $50 \%$ showed mortality (EC50) after the first day with $65 \%$ for extracts of L. pauciliforum, S. glaucum, $N$. pacifica and with $75 \%$ for extract of $X$. macrospiculat. Moreover, such concentration showed mortality (EC50) increased continueously after the second day until it reached into $95 \%$ for extracts of L. pauciliforum and S. glaucum, and reached into $100 \%$ for extracts of $N$. pacifica and $X$. macrospiculata. However, our data summarized that the more the crude extract ratio, the more the mortality of Artimia salina larvae.

Table 4: Cytotoxicity $\left(\mathrm{EC}_{50}\right)$ of the athanolic crude extraxts of L. pauciliforum, S. glaucum, N. pacifica and $X$. macrospiculata to Artemia salina $\left(M m_{c t}\right.$ is mortality of individuals in time $\mathrm{t}(\%)$ and $N_{M m}$ is average number of died individuals).

\begin{tabular}{|c|c|c|c|c|c|c|c|c|c|}
\hline \multirow{3}{*}{ conc. (\%) } & \multirow{3}{*}{ Species } & \multicolumn{8}{|c|}{ Incubation period (day) } \\
\hline & & \multicolumn{2}{|r|}{1} & \multicolumn{2}{|c|}{2} & \multicolumn{2}{|c|}{3} & \multicolumn{2}{|c|}{4} \\
\hline & & $N_{M m}$ & $M m_{c t}$ & $N_{M m}$ & $M m_{c t}$ & $N_{M m}$ & $M m_{c t}$ & $N_{M m}$ & $M m_{c t}$ \\
\hline \multirow{4}{*}{1} & L. pauciliforum & 0 & 0 & 1 & 3 & 4 & 10 & 10 & 25 \\
\hline & S. glaucum & 0 & 0 & 3 & 8 & 8 & 20 & 11 & 28 \\
\hline & N. pacifica & 0 & 0 & 1 & 3 & 6 & 15 & 11 & 28 \\
\hline & X. macrospiculata & 1 & 3 & 4 & 10 & 8 & 20 & 13 & 33 \\
\hline \multirow{4}{*}{3} & L. pauciliforum & 2 & 5 & 5 & 13 & 10 & 25 & 13 & 33 \\
\hline & S. glaucum & 2 & 5 & 4 & 10 & 7 & 18 & 14 & 35 \\
\hline & N. Pacifica & 3 & 8 & 5 & 13 & 9 & 23 & 13 & 33 \\
\hline & X. macrospiculata & 4 & 10 & 7 & 18 & 10 & 25 & 15 & 38 \\
\hline \multirow{4}{*}{5} & L. pauciliforum & 5 & 13 & 10 & 25 & 15 & 38 & 20 & 50 \\
\hline & S. glaucum & 6 & 15 & 10 & 25 & 14 & 35 & 19 & 48 \\
\hline & N. pacifica & 6 & 15 & 12 & 30 & 16 & 40 & 21 & 53 \\
\hline & X. macrospiculata & 7 & 18 & 13 & 33 & 18 & 45 & 22 & 55 \\
\hline \multirow{4}{*}{10} & L. pauciliforum & 9 & 23 & 14 & 35 & 20 & 50 & 26 & 65 \\
\hline & S. glaucum & 12 & 30 & 18 & 45 & 22 & 55 & 29 & 73 \\
\hline & N. pacifica & 11 & 28 & 18 & 45 & 21 & 53 & 29 & 73 \\
\hline & X. macrospiculata & 14 & 35 & 20 & 50 & 26 & 65 & 30 & 75 \\
\hline \multirow{4}{*}{20} & L. pauciliforum & 15 & 38 & 19 & 48 & 25 & 63 & 31 & 78 \\
\hline & S. glaucum & 15 & 38 & 20 & 50 & 27 & 68 & 32 & 80 \\
\hline & N. pacifica & 16 & 40 & 22 & 55 & 29 & 73 & 33 & 83 \\
\hline & X. macrospiculata & 18 & 45 & 23 & 58 & 30 & 75 & 35 & 88 \\
\hline \multirow{4}{*}{50} & L. pauciliforum & 26 & 65 & 31 & 78 & 35 & 88 & 37 & 93 \\
\hline & S. glaucum & 26 & 65 & 33 & 83 & 35 & 88 & 38 & 95 \\
\hline & N. pacifica & 25 & 63 & 32 & 80 & 36 & 90 & 40 & 100 \\
\hline & X. macrospiculata & 28 & 70 & 33 & 83 & 37 & 93 & 40 & 100 \\
\hline control & & 0 & 0 & 0 & 0 & 2 & 5 & 5 & 12.5 \\
\hline
\end{tabular}




\section{DISCUSSION}

The overall objective of the current study was to screen the ability of organic extracts of the soft corals collected from the Egyptian Red Sea coast to inhibit the growth of certain reference bacteria. Nowadays, research about marine natural products to control diseases appeared as an impact of pathogenic bacteria. Porifera (sponges) and Chordata (including ascidians) have dominated as the major contributing phyla of novel bioactive compounds (Blunt et al., 2007). The secretions from soft corals exhibit a defense mechanism (Shnit-Orland and Kushmaro, 2008). Bowden et al. (1984) discovered that Gorgonian soft coral; Lobophytum crasscopiculatum tend to yield compound; identified as cembranolides which have antimicrobial activities.

Badria et al. (1997) investigated bioactivity-guided fractionation of an alcohol extract of the soft coral Sarcophyton sp. collected from coral reefs near Hurghada, Red Sea, Egypt afforded a new lactone cembrane diterpene, sarcophytolide 1. The structure was deduced based on its spectroscopic data and from comparison with the spectral data of known closely related cembrane-type compounds. This compound exhibits good antimicrobial activity towards Staphylococcus aureus, Pseudomonas aeruginosa, Candida albicans, and Saccharomyces cerevisiae activity. The bioactivity-guided fractionation of an alcohol extract of the soft coral Sarcophyton glaucum near Hurghada, Red Sea, Egypt resulted in the isolation of a new lactone cembrane diterpene, sarcophytolide (Badria et al., 1998). In antimicrobial assays, the isolated compound exhibited a good activity towards Staphylococcus aureus, Pseudomonas aeruginosa, and Saccharomyces cerevisiae. Sarcophytolide was found to display a strong cytoprotective effect against glutamate-induced neurotoxicity in primary cortical cells from rat embryos. Preincubation of the neurons with 1 or 10 $\mu \mathrm{g} / \mathrm{ml}$ of sarcophytolide resulted in a significant increase of the percentage of viable cells from $33 \pm 4 \%$ (treatment of the cells with glutamate only) to $44 \pm 4$ and $92 \pm 6 \%$, respectively. Administration of sarcophytolide during the post-incubation period following glutamate treatment did not prevent neuronal cell death. Pretreatment of the cells with sarcophytolide for 30 min significantly suppressed the glutamate-caused increase in the intracellular $\mathrm{Ca}^{2+}$ level $\left(\left[\mathrm{Ca}^{2+}\right]_{\mathrm{i}}\right)$. Evidence is presented that the neuroprotective effect of sarcophytolide against glutamate may be partially due to an increased expression of the proto-oncogene $b c l-2$.

The coral secondary metabolite, sarcophytolide, might be of interest as a potential drug for treatment of neurodegenerative disorders.

Kelman et al. (2006) examined the antibacterial activity of five soft corals and found that only Dendronephthya hemprichi was active against the test bacteria. However, Dendronephthya hemprichi differs from the other five soft corals by the lack of symbiotic relationship with the dinoflagellate zooxanthellae. It therefore will be interesting to investigate the role of symbiotic zooxanthellae, as well as associated bacteria, in the production of natural products, especially metabolites that target cooccurring and potentially harmful microorganisms. Moreover, Kelman et al. (2006) explained that extracts with a low natural (whole-tissue) concentration exhibit high activity in laboratory assays indicates the presence of a highly potent compound. The corals that were used varied in their extract concentration and were not consistent with their antimicrobial activity. For example, Sarcophyton glaucum had a high mean extract concentration of $212.2 \mathrm{mg} \mathrm{cm}^{-3}$ but showed a much lower activity than $X$. macrospiculata that had a lower mean extract concentration of $41.9 \mathrm{mg} \mathrm{cm}^{-3}$. These results indicated that the extracts of these corals differ in their chemical composition 
as well as the potency of the active metabolites. Ali and Soliman (2009) studied the antifouling activity of crude extracts of 5 common Red Sea soft corals. The extracts were mixed with a marine paint, applied to PVC panels immersed in the seawater of Suez Bay (Red Sea). Extracts of Sinularia heterospiculata and Sinularia variabilis showed the highest and potent wide spectrum antifouling activity, particularly in the first 17 days of fouling formation. Extracts of Sinularia polydactyla exhibited significant selective inhibition against settlement of barnacle, while the extracts of Lithophyton arboreum showed significant antifouling activity against the latter successional stages of tube worms.

The results of the current study propose that these soft corals may contain bioactive compounds with antifouling activity. They stated that these bioactive molecules can be isolated, purified, identified and chemically synthesized for commercial uses in the development of nontoxic and environmentally acceptable antifouling coatings. Cheng et al. (2009) have extracted three metabolites from the Formosan soft coral Nephthea erecta and one metabolite from Nephthea chabroli. In vitro, they examined their antimicrobial activities. Metabolite (1) exhibited antibacterial activity against Enterobacter aerogenes (ATCC13048), Serratia marcescens (ATCC25419), Salmonella enteritidis (ATCC13076), Yersinia enterocolitica (ATCC23715), and Shigella sonnei (ATCC11060). Analysis of $H$. fuscescens has led to the isolation of 6-hydroxy $-\alpha$ - muurolene (1), gorgosten-5(E)-3 $\beta$-ol (2), 1-nonadecyloxy-2,3-propanediol (3) and $(2 S, 3 R, 4 E, 8 E)-N$-hexadecanoyl-2amino 4,8-octadecadiene-1,3-diol (4) and sarcoaldosterol A (5) (Mohammed et al., 2011). The isolated compounds were reported from several marine organisms and are identified for the first time from the soft coral $H$. fuscescens collected from the Red Sea.

The minimal inhibitory concentrations (MICs) using disc - diffusion technique were determined against the most affected bacterial pathogens (E. coli and S. aureus), applying seven concentrations $\left(50,100,200,300,500,700\right.$ and $1000 \mathrm{mg} \mathrm{ml}^{-1}$ ) for each crude extract obtained either by ethanol $70 \%$ or ethyl acetate. The level of activity that is measured in the well-cut diffusion assay depends on both the rate of diffusion of the extract into the agar and the potency of the extract. Extracts that contain highly active compounds (i.e., more potent), but have physical properties that generate a lower diffusion rate, may appear to have low activity in the assay. This problem can be overcome by performing MIC assays in liquid media, as was shown for the cat (Kelman et al., 2001). The concentration of a potent compound in the crude extract is also a major factor in the activity score that is observed in laboratory assays. The usage of antibiotic disc susceptibility tests or disc-diffusion assays has the ability to rapidly identify active metabolites and therefore is particularly useful in the initial screening for antimicrobial activity and as the means for following activity during chemical purification (Jenkins et al., 1998). Kelman et al., (2001) found that the MIC of the coral crude extract against the Vibrio sp. strain $P$ - $l$ was $1.25 \mathrm{mg} \mathrm{ml}^{-1}$, while the mean natural extract concentration of Parerythropodium fulvum fulvum was $28 \mathrm{mg}$ $\mathrm{ml}^{-1}$. This result explains the high antimicrobial activity observed in the disc-diffusion method. Both concentrations 1 and 3\% of ethanolic crude extracts of the present study did not show mortality at EC50 during the incubation period of toxicity experiment. Whereas, the concentration 5\% showed mortality (EC50) after the fourth day for extracts of L. pauciliforum, S. glaucum, N. pacifica and X. macrospiculata, respectively. However, our toxicity data confirmed that the more the crude extract ratio, the more the mortality of Artemia salina larvae. Parallel to the results of Said, (2005) who detected cytotoxicity of cembranolide extracted from soft corals; 
Lobophytum crassum and L. rotundum against brine shrimp Artemia salina larvae. Duh et al., (2004) discovered eight cytotoxic steroids and sesquiterpenoids (coded from 1-8). Compounds 1, 4, and 5 exhibited cytotoxicity against P-388 cells with ED50 values of 9.45, 8.93, and $16.3 \mu \mathrm{M}$, respectively. Compounds 4 and 5 exhibited cytotoxicity against HT-29 cells with ED50 values of 9.03 and $10.5 \mu \mathrm{M}$, respectively.

\section{CONCLUSIONS}

This work introduces some important data that can be summarized in the following points:

1. The Soft coral species obtained in this study proved evidence that soft corals are valuable as a source of new bioactive molecules.

2. The compound(s) produced by soft corals possess an antimicrobial activity against a number of Gram-positive and Gram-negative bacteria.

3. The inhibitory effect of these compound(s) against human pathogens such as S. aureus ATTC 6538 and P. aeruginosa ATTC 8739 suggests promising applications in the clinical field.

4. The inhibitory effect of these compound(s) against fish pathogens such as $V$. damsela and $V$. fulvialis suggests promising applications in the aquaculture field.

\section{REFERENCES}

Al-Ajlani, M.M. and Hasnain, S. (2006). Simple and rapid isolation of a novel antibiotic from Bacillus subtilis Mz-7. J. Liquid Chromatog. Related Technol. 29: 639-647.

Ali, M.A.A. and Soliman, Y.A-A (2009). Antifouling activity of crude extracts from some Red Sea soft corals. Natural products, 32.

Badria, F, A.; Guireguis, A.N. and El-Naggar, W.A. (1997). Antibacterial and Antifungal Agents from Egyptian Marine Organisms. 35 (4): 284-287.

Badria, F.A.; Guirguis A.N.; Perovic S.; Steffen R.; Müller, W.E.G. and Heinz, C.S. (1998). Sarcophytolide: a new neuroprotective compound from the soft coral Sarcophyton glaucum. Toxicology, 131, 2-3, 16: 133-143.

Badria, F, A.; Guireguis, A.N. and El-Naggar W.A. (1997). Antibacterial and Antifungal Agents from Egyptian Marine Organisms. Pharm. Biol. 35 (4): 284287.

Ballantine, D.L.; Gerwick,W.H.; Velez, S.M.; Alexander, E. and Guevara, P. (1987). Antibiotic activity of lipid-soluble extracts from Caribbean marine algae. Hydrobiologia, 151/152: 463-469.

Banduraga, M.M.; Fenical, W.; Donovan, S. F. and Clardy, J. (1982). Pseudopterolide, an irregular diterpenoid with unusual cytotoxic properties from the Caribbean sea whip Pseudopterogorgia acerosa (Pallas) (Gorgonacea). J. Am. Chem. Soc. 104 (23): 6463-6465.

Bhakuni, D. S. and Rawat, D. S. (2005). Bioactive Marine Natural Products. Springer, New York, New York.

Blunt, J.W.; Copp, B.R.; Hu, W.P.; Munro, M.H.G.; Northcote, P.T.M. and Prinsep, R. ( 2007). Marine natural products. Nature Products Reports, 24: 31-86.

Borowitzka, M. A. and Borowitzka, L. J. (1992). vitamins and chemicals from microalgae. In In: Microalgal biotechnology, pp. 179. 
Bowden, B.F.; Coll, J.C.; Decosta, M.S.L.; Mackay, F.M.; Mahendra, M.; De Silva, E.D. and Wills, R. H. (1984). The structure determination of a new cembranolide diterpene from the soft coral Lobophytum cristigalli (Coelenterata, Octocorallia, Alcyonacea) Aust. J. Chem. 37: 545-552.

Cheng, S-Y.; Huang, Y-C.; Wena, Z-H.; Chiou S-F.; Hsu S-K.W.C-H.; Dai C-F. and Duh, C-Y. (2009). Novel sesquiterpenes and norergosterol from the soft corals Nephthea erecta and Nephthea chabroli. Tetrahedron Letters, 50: 802-806.

Coll, J. C.; Leone, P. A.; Bowden, B. F.; Carroll, A. R. and Konig, G. M. (1995). Chemical aspects of mass spawning in corals. II. (-)-Epi-thunbergol, the sperm attractant in the eggs of the soft coral Lobophytum crassum (Cnidaria: Octocorallia). Mar. Biol. (Berl.), (123): 123 - 143.

Duh, C-Y.; El-Gamal, A.A.H.; Song, P-Y.; Wang, S-K. and Dai, C-F. (2004). Steroids and Sesquiterpenoids from the Soft Corals Dendronephthya gigantean and Lemnalia cervicorni. J. Nat. Prod. 2004, 67, 1650-1653.

Dvorak, P.; Šucman, E.; Červenakova, D.; Korinek, K. and Blechova, R. (1999). Utilization of bioassay with Artemia salina in pharmacotoxicology. In: Collection of abstracts from $9^{\text {th }}$ conference on Toxicity and biodegradability of wastes and chemicals significant in aquatic environment. Soláň, Czech Republic, 13. -15. 9.1999.

EL-Masry, M.H.; Khalil, A.I.; Hassouna, M.S. and Ibrahim, H.A.H. (2002). In situ and in vitro suppressive effect of agricultural composts and their water extracts on some phytopathogenic fungi. World J. Microbiology and Biotechnology, 18: 551-558.

Ezz-AlArab, M. A. (2009). Studies on Soft Corals (Octocorallia, Alcyonacea) Inhabiting Coral Reefs of Some Red Sea Areas, Egypt. M.Sc thesis. Zoology Dept. Fac. Scie. Tanta university

Febles, C. I.; Arias, A. and M.C. Gil-Rodriguez (1995). In vitro study of antimicrobial activity in algae (Chlorophyta, Phaeophyta and Rhodophyta) collected from the coast of Tenerife (in Spanish). Anuario del Estudios Canarios 34: 12

Gohar, H. A. F. (1940). Studies on the Xeniidae of the Red Sea. Publ. Mar. Biol. Sta. Ghardaqa, Red Sea, Egypt, 2: 25-118.

Groweiss, A.; Fenical, W.; Cun-Heng, H.; Clardy, J.; Zhongde, W.; Zhongnian, Y.; Kanghov, L. (1985). Subergorgic acid, a novel tricyclopentanoid cardio- toxin from the Pacific gorgonian coral Subergorgia suberosa. Tetrahedron Letters, 26(20):2379-2382.

Jenkins, KM.; Jensen, PR. and Fenical, W. (1998). Bioassay with marine organisms: Part 11. Marine microbial chemical ecology. In: Haynes K, Millar JC (eds) Methods in chemical ecology Chapman and Hall, New York: 1- 32.

Kelman, D.; Kashman, Y.; Rosenberg, E.; Ilan, M.; Ifrach, I. and Loya, Y. (2001). Antimicrobial activity of the reef sponge Amphimedon viridis from the Red Sea: evidence for selective toxicity. Aquat. Microb. Ecol. 24:9-16.

Kelman, D.; Kashman, Y.; Rosenberg, E.; Kushmaro, A. and Loya, Y. (2006). Antimicrobial activity of Red Sea corals. Marine Biology, 149: 357-363.

Mayer, A. M. S. and Hamann, M. T. (2005). Marine pharmacology in 2001-2002: Marine compounds with anthelmintic, antibacterial, anticoagulant antidiabetic, antifungal, anti-inflammatory antimalarial, antiplatelet, antiprotozoal, antituberculosis and antiviral activities; affecting the cardiovascular, immune and nervous systems and othermiscellaneous mechanisms of action. Comp. Biochem. Phys. 140- 21. 
Mohammed, R.; Seliem, M.A.; Mohammed, T.; Abed El Fatah, A.; Murad, A. and Thabet, M. (2011).Bioactive Secondary Metabolites from the Red Sea soft coral Heteroxenia fuscescens. IJARNP. 4(4):

Parveez, G.K.A.; Abdul Majid, N.; Alizah, Z. and Abdul Rasid, O. (2007). Determination of minimal inhibitory concentration of selectionagents for selecting transformed immatureembryos of oil palm. Asia Pacific Journal of Molecular Biology and Biotechnology, 15 (3): 133-146.

Said, S. A. (2005). An Antimalarial Cembranolide from Tanzania Soft Corals, Lobophytum Crassum (von Marenzeller (1886) and L. Rotundum (TixierDurivault (1957). Western Indian Ocean J. Mar. Sci. 4 (1): 95-98.

Sammarco, P.W.; Coll, J.C. and La-Barre, S. (1985). Competitive strategies of soft corals (Coelenterata: Octocorallia): II. Variable defensive responses and susceptibility to scleractinian corals. Journal of Experimental Marine Biology and Ecology, vol. (91): 199-216.

Shnit-Orland, M. and Kushmaro, A. (2008). Coral mucus bacteria as a source for antibacterial activity Proceedings of the 11th International Coral Reef Symposium, Ft. Lauderdale, Florida, 7-11. Session number 8.

Somnath, C. and Ghosh, U. (2010). Oceans: A Store house Of Drugs - A Review. Journal of Pharmacy Research 2010, 3, 4.

Taglialatela-Scafati, O.; Deo-Jangra, U.; Campbell, M.; Roberge, M.; Andersen, R. J. (2002). Diterpenoids from Cultured Erythropodium caribaeorum. Org. Lett. 4: 4085-4088

Thomson, J. A. and Dean, L. M. I. (1931). Alcyonacea of the SIBOGA Expedition, with an addendum of Gorgonacea, vol. $\left(\right.$ XIII $\left._{d}\right)$ 1-227. 


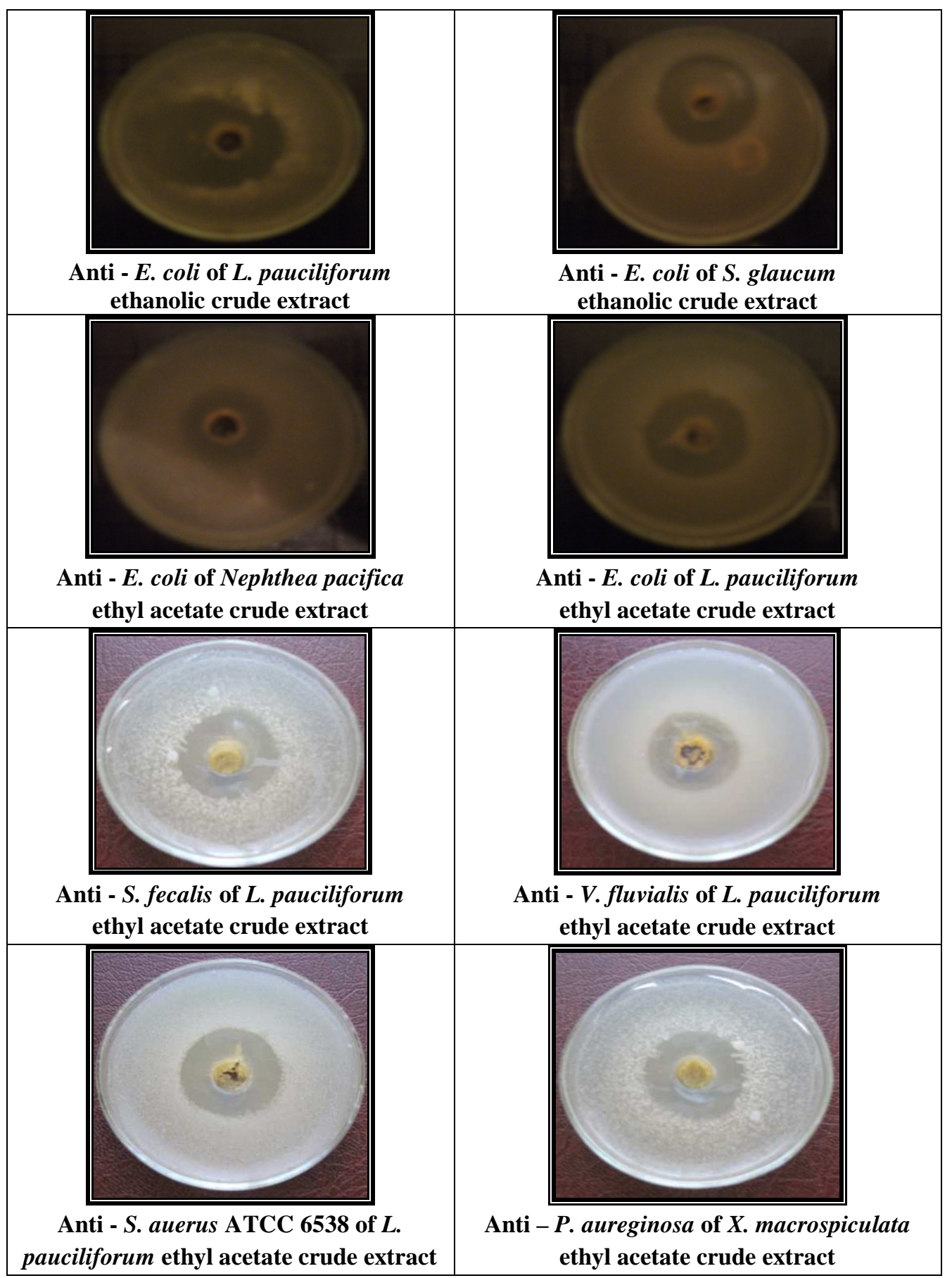

Fig. 1: Macrographs showing the most records of antibacterial activities of tested crude extracts. 


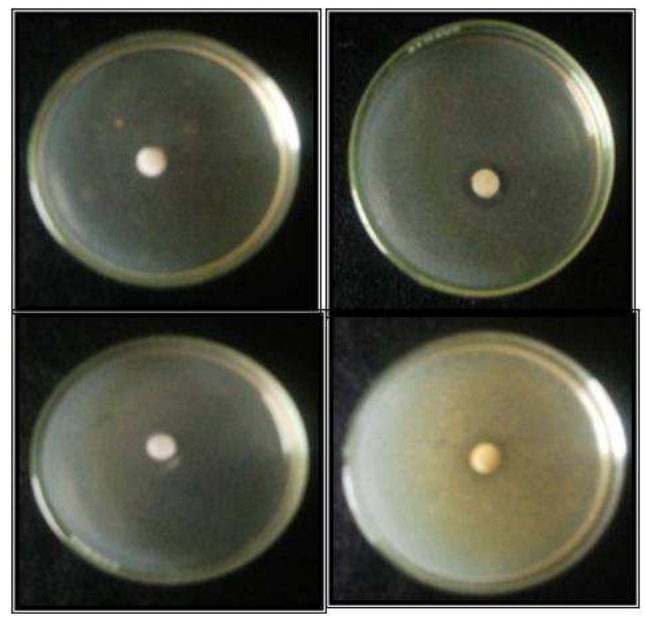

Fig. 2: Macrographs showing the inhibition zone MIC of crude extracts against $E$. coli (upper) and its control and against $S$. aureaus ATCC 6358 (lower) and its control 


$$
\begin{aligned}
& \text { النشاط الضد بكتيرى لبعض أنواع المرجاتيات اللينة بالبحر الأحمر }
\end{aligned}
$$

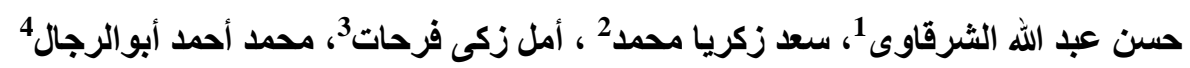

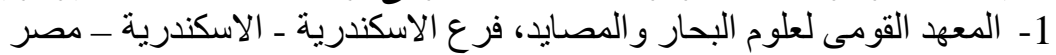

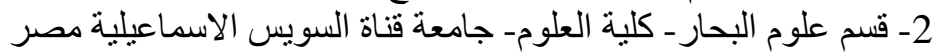

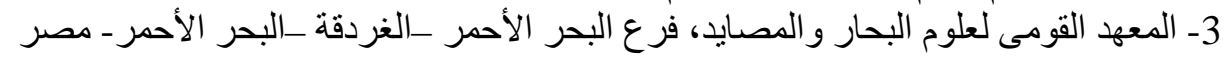

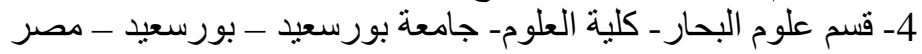

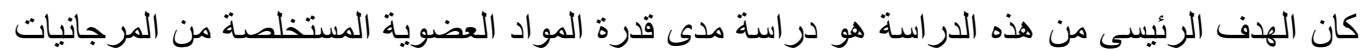

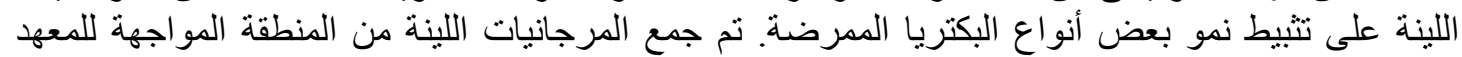

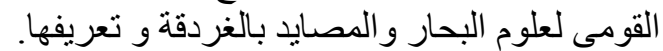

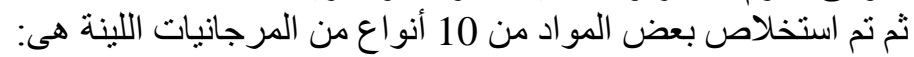
‘Sarcophyton glaucum ‘Sarcophyton Dendronephthea sp. 'Lopophytum pauciliforum acutum Lopophytum 'Sarcophyton acutum 'Nephthea pacifica rgardineiri Sinularia macrospiculata Xenia Sarcophyton ثم تم اختبار فعالية المو اد المستخلصة من المرجانيات اللينة ضد بعض البكتيريا التى تصيب كل من

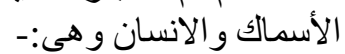

Staphylococcus aureus ATCC 6538, Pseudomonas aeruginosa ATCC 8739, Vibrio damsela, Vibrio fulvilalis, Bacillus cereus, Bacillus cereus 1318, Enterococcus faecalis, Escherichia coli Fusarium oxysporum.

أظهرت النتائج أن وحدة النشاط المطلقة Absolute activity unit (AU) للمستخلص الناتج من الكحول الإيثيلى تراوحت بين 1.4 و 25 لكل من Sarcophyton acutum و م. pauciliforum ف. بصفة عامة أظهرت كل من المواد المستخلصة باستخدام الكحول الايثيلى والايثيل اسيتات قدرة

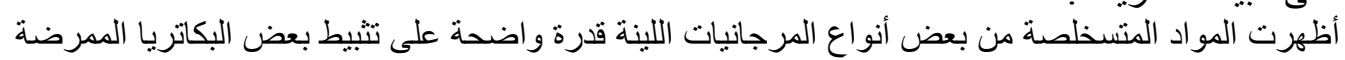

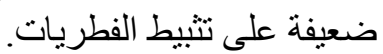
مما بدل على امكانية استخدامها فى الأغر اض الطبية والع العلاجية المختلفة. 